\title{
State advances and private retreats? - Evidence of aggregate productivity decomposition in China
}

\author{
Jun DU ${ }^{\mathrm{a}, \mathrm{b}, *}$, Xiaoxuan LIU $^{\mathrm{c}}$, Ying ZHOU ${ }^{\mathrm{d}}$ \\ a Enterprise Research Centre, UK \\ b Stockholm China Economic Research Institute, Stockholm School of Economics, PO Box 6501, 11383 Stockholm, Sweden \\ c Institute of Economics, Chinese Social Science Academy, 2 Yue Tan Bei Xiao Jie, Beijing 100836, China \\ d Economics and Strategy Group, Aston Business School, Aston University, Birmingham B4 7ET, UK
}

\section{A R T I C L E I N F O}

\section{Article history:}

Received 17 September 2013

Received in revised form 23 January 2014

Accepted 7 March 2014

Available online 1 April 2014

\section{JEL classifications:}

014

D24

C10

047

P3

Keywords:

Industrial development

Reallocation

Decomposition

Aggregate productivity

China

\begin{abstract}
A B S T R A C T
This paper is motivated by the recent debate on the existence and scale of China's 'Guo Jin Min Tui' phenomenon, which is often translated as 'the state sector advances and the private sector retreats'. We argue that the profound implication of an advancing state sector is not the size expansion of the state ownership in the economy per se, but the likely retardation of the development of the already financially constrained private sector and the issues around the sustainability of the already weakening Chinese economy growth. Drawing on recent methodological advances, we provide a critical analysis of the contributions of the state and non-state sectors in the aggregate Total Factor Productivity and its growth over the period of 1998-2007 to verify the existence of GJMT and its possible impacts on Chinese economic growth. Overall, we find strong and consistent evidence of a systematic and worsening resource misallocation within the state sector and/or between the state sectors and private sectors over time. This suggests that non-market forces allow resources to be driven away from their competitive market allocation and towards the inefficient state sector.
\end{abstract}

Crown Copyright @ 2014 Published by Elsevier Inc. All rights reserved.

\section{Introduction}

The private sector in China has been the engine of the remarkable economic growth (Allen, Qian, \& Qian, 2005; Huang, 2008). In fact, privatization, as well as political decentralization and regional centralization and competition, are the three centerpieces of the fundamental institutional reform and development in China that explain the unprecedented economic growth in the last three decades (Xu, 2011). However, a recent debate on "Guo Jin Min Tui" in China (GJMT hereafter), translated as "the state sector advances and the private sector retreats", has repeatedly made its appearance in the media around the world, suggesting the possible retreat of China's market-oriented reforms (for example The Economist, 2011; Xu, 2009). Some argue that, since 2005, there has been a trend of the state sector expanding market power and pushing private firms into the fringe.

There is insufficient and inconsistent evidence to support or dispute the presence and the scale of such a phenomenon. If one takes GJMT simply as the growing share of the state sector in the aggregate economy, then the statistics indicate the exact opposite. Officially the state sector as a whole has been slimming down sharply over the years, while firms in the non-state sector

\footnotetext{
* Corresponding author at: Economics and Strategy Group, Aston Business School, Aston University, Birmingham B4 7ET, UK. Tel.: +44 1212043340.

E-mail addresses: j.du@aston.ac.uk (J. Du), xxliu@cass.org.cn (X. Liu), y.zhou8@aston.ac.uk (Y. Zhou).
} 
prospered. Hu (2012) among others shows that the size, production, employment, profitability and tax contribution of the state sector clearly contracted.

However, it is impossible to overlook the gigantic position of the state sector in the Chinese economy. Not only Chinese state-owned enterprises (SOEs) have an increasing presence in the Fortune list, ${ }^{1}$ but also large Chinese SOEs are becoming the dominant force in both domestic and international markets (Elliott \& Zhou 2013; Hsueh, 2011). The Economist (2011) argues that the Chinese government may have been muscling in on business in a variety of ways, not only by tightening its grip on strategic industries, but also devising market-access rules to favor state companies, to the chagrin of private businesses. In addition, over a decade into the initial privatization reform, SOEs surprisingly remain active in a wide range of palpably non-strategic sectors, from textiles and papermaking to catering (Du \& Liu, 2012). In fact, we can draw a quite telling picture of the evolution of firm's operating scale among the state-owned, domestic private and foreign firms using the aggregate official statistics. Fig. 1 demonstrates some of the remarkable differences in the operating scales between the three sectors, defined either by average total assets per firm or by average total employees per firm in the last decade or so. While the average size of the private and foreign firms does not seem to differ very much over the period, the state sector firms have scaled up considerably.

Has the state advanced and the private retreated? The large amount of attention that this puzzle has attracted in the popular press lately is just indicative of its importance. In fact, one might take a step back and in the spirit of Deng Xiaoping ${ }^{2}$ ask why does this matter. We argue that what matters is not just the size expansion of the state ownership itself or an implicit halt of the on-going privatization, nor the relative proportion of the sectors in the economy, but rather whether this movement leads to or hinders the economic development and growth of the country. If the expansion of the state sector means restraining the already resource-constrained private sector, and consequently a digression of economic progress, then the implications of the shifted policy towards GJMT would be alarmingly profound. In a boarder context where the recent crisis of liberal capitalism has seen rendered more seriously by the rise of the alternative state capitalism (Wooldridge, 2012), it is important to reassess the costs and benefits of the visible hand melding with the power of the invisible one. Clearly, either direction of the argument requires significant qualification before suggesting a way forward.

This paper endeavors to disentangle the puzzle by comparing the contributions of the state and non-state sectors in the aggregate Total Factor Productivity (henceforth TFP) and its growth. TFP is a well-understood source of long-run economic growth, and recently has been recognized as the main driver of the global inequality (Hall \& Jones, 1999; Hsieh \& Klenow, 2009). This paper also contributes the discussion around the tendency of China falling into the "Middle Income Trap" (MIT for short) (see among others Woo, Lu, \& Sachs, 2012). As it becomes increasingly clear, stagnated economic growth is strongly associated with slow productivity growth (Aiyar, Shekhar, et al., 2013). Hence the key to resolve the MIT problem also boils down to promoting productivity in essence.

In general, aggregate productivity can increase in two ways. First, when the average individual firm productivity improves through, for example, technology upgrading and improved management practice. Put simply, aggregate productivity increases when an average firm becomes more productive. A large literature is devoted to informing us how this process may happen (Syverson, 2011). Second, aggregate productivity increases when resources, such as labor and capital, flow from less productive firms to more productive ones. In other words, aggregate productivity rises by downsizing or even closing down the less productive firms and by allowing the better ones to grow. In this sense, even without raising the productivity level of an average firm, aggregate productivity may still increase.

The recent literature built upon cross-country comparisons and individual country case studies show that resource misallocation across firms within a given industry is an important contributing factor of the large and persistent dispersion in aggregate productivity (Bartelsman, Haltiwanger, \& Scarpetta, 2013; Hsieh \& Klenow, 2009). Closely relevant to these findings is the recent enquiry of how globalization facilitates structural change and productivity growth across countries. McMillan and Rodrik (2011) identify that large labor productivity gaps between countries are driven by growth-reducing structural change between sectors. The resource misallocation due to resource directed to certain sectors, such as from manufacturing to informality or clinging to resource-reliant sectors, explains the lack of productive performance of Latin America and African countries. China, among a group of developing countries, has done pretty well in this aspect (McMillan \& Rodrik, 2011).

Yet China has a different set of problems. Given that so much has been learned from the Chinese institutional background (Xu, 2011), the well documented soft-budget constraints and the poorly performing SOEs (Jefferson \& Su, 2006), and the widespread financial constraints to the private sector, private SMEs in particular (Allen et al., 2005; Bai, Lu, \& Tao, 2006), our main objective in this paper is twofold. First, to examine the role of state ownership in driving the components of aggregate productivity and its growth, and second, based on the robust evidence of this, to reflect on the presence of GJMT.

To achieve this aim, we derive the sources of TFP gains by adopting the recently improved methodology of Melitz and Polanec (2012) which allows to decompose the aggregate TFP and its growth into the contributing components of average individual firms' productivity improvements, resource allocative effects, and industrial creative destruction (i.e. entry and exit). Based on these results, we compare and contrast the roles of the state versus private sectors in shaping the aggregate productivity level and its growth. We postulate that if there has been a consistent, systematic and more importantly worsening resource misallocation

\footnotetext{
${ }^{1}$ Of the 42 Mainland Chinese companies in the Fortune 500 list of the world's biggest firms in 2010, all but three were owned by the government (The Economist, 2011).

2 Deng Xiaoping was the second-generation leader of China, who famously quoted "white cat or black one does not matter, a cat that catches mice is a good cat" to make the point that it does not matter if it was capitalist or socialist system, what matters is the economic results.
} 


\section{a) By average total assets per firm}

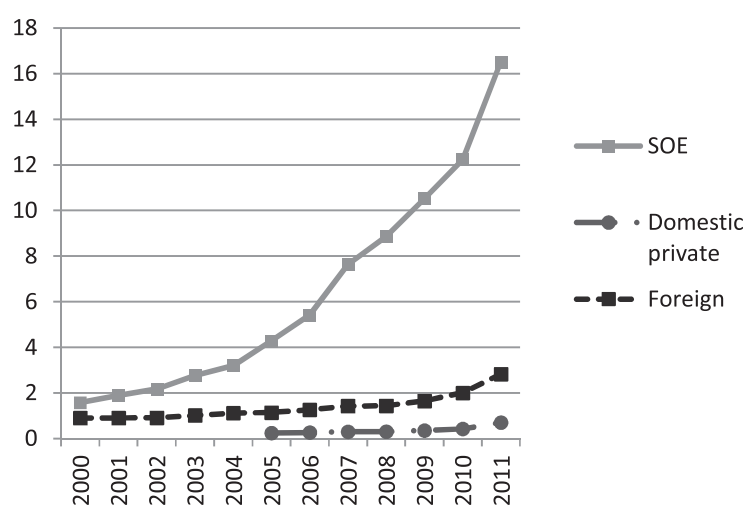

b) By average total employees per firm

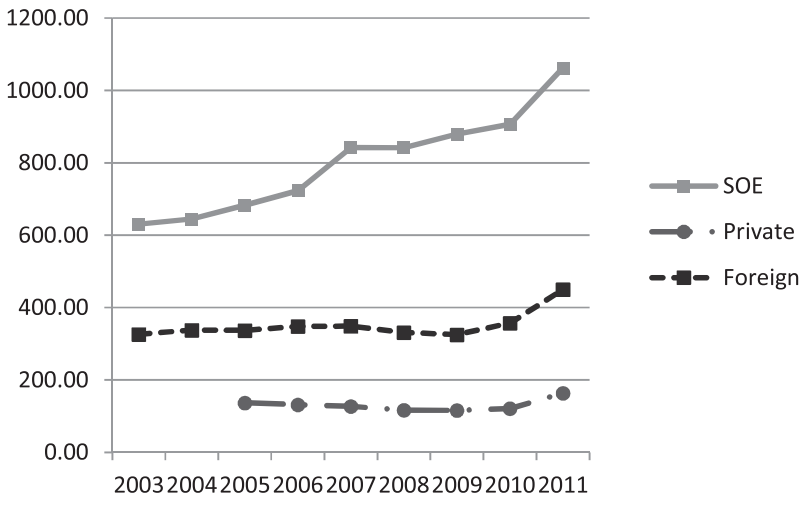

Note: The figure shows the temporal changes of (a) average assets per firm and (b) average total employees per firm in the three sectors (by official registration), state-owned enterprises, domestic private enterprise and foreign-invested enterprises, recorded in the official annual statistics.

Source: China Statistical Yearbook, various issues (1999-2012).

Fig. 1. Operating scale of the Chinese manufacturing firms. a: By average total assets per firm. b: By average total employees per firm.

within the state sector and/or between the state sectors and private sectors over time, it would suggest that the presence (or the market power) of the state sector allowed resources to be driven away from the best-use allocation by what a competitive market would achieve otherwise. Consequently, the continuing survival and the expansion (i.e. failure to contract or close down) of the inefficient state firms impelled by nonmarket forces would indicate the advances of the state sector at the expense of the deprivation of the private sectors.

Overall, our results tell a simple albeit compelling story. We find strong and consistent results of the overall weakening technical progress and a significant resource misallocation among the Chinese manufacturing firms over the recent decade; this promptly echoes the slowdown of the Chinese economic growth. The weak performance of the state sector firms is still a significant obstacle to Chinese economic growth in terms of both relatively sluggish technical progress and poor resource allocation. We demonstrate the evidence to support the view that GJMT phenomenon may have taken place in the past decade at the expense of significant aggregate productivity growth and economic development.

The remainder of the paper proceeds as follows. Section 2 outlines the methodology of the TFP measure, the decomposition of aggregate productivity and growth. Section 3 introduces and describes the data. Section 4 reports our findings and discusses the interpretations and implications. We conclude in Section 5.

\section{Methodology}

\subsection{Productivity measure}

We measure firm productivity by TFP. ${ }^{3}$ Given the available methods of measuring TFP, we turn to Olly and Pakes (1996) approach in which a non-parametrically inverted investment equation is used to instrument real capital in the production function, so as to mitigate the simultaneity and sample selection due to entry and exit. ${ }^{4}$ Nevertheless, on the sensitivity of using different methodologies to estimate productivity, Van Biesebroeck (2007) and Elliott and Zhou (2013) find different estimates to exhibit very high correlations. We discuss the measurement issues of output and inputs of production function in Section 3. The details of the identification strategy of the input elastics of production can be found in Olly and Pakes (1996).

Aggregate productivity measures the overall productivity level of an economy, which is a weighted average of individual firm level productivity, as in:

$$
\Phi_{t}=\sum_{i} s_{i t}^{k} \phi_{i t}
$$

\footnotetext{
${ }^{3}$ The most commonly used measures of individual firm productivity are labor productivity and TFP. While the former is simple and straightforward to calculate and particularly handy in cross-country comparison (Bartelsman et al., 2013), it does not count for capital inputs in deriving productive efficiency. In the context of China where capital investment is heavy, TFP is a much preferred measure to labor productivity.

${ }^{4}$ Brandt, Van Biesebroeck, and Zhang (2012) applied the same TFP estimation approach on the same data which provides the additional motivation of adopting it for comparison purposes.
} 
where $\Phi_{t}$ and $\phi_{i t}$ denote aggregate productivity and firm $i$ 's individual productivity at time $t$. $s_{i t}^{k}$ denotes the weight of individual firm $i$ in the economy at time $t$ based on the weighting scheme $k$, hence $\sum s_{i t}^{k}=1$. In the baseline analysis, we use value-added weighting scheme as in Brandt, Van Biesebroeck and Zhang (2012), given that our production function is value-added based. We further test the sensitivity of the decomposition results to different weighting schemes based on employment and fixed capital. This will be discussed in detail in Section 4.3.

\subsection{Productivity decomposition}

Different methods have been proposed in the literature to decompose the aggregate productivity level and its changes over time (see Baily, Hulten, \& Campbell, 1992; Foster, Haltiwanger, \& Krizan, 2001; Griliches \& Regev, 1995). Melitz and Polanec (2012) recently point out two drawbacks of these existing methods. Firstly, since the decomposition of aggregate productivity in these studies is based on the comparison of individual surviving firms' market shares over time, it does not measure the difference between an individual firm's actual market share with its potential market share under a random allocation in perfectly competitive market. Hence, these methods do not provide full insight into the magnitude of resource misallocation due to market failure. Secondly, the existing approaches derive the contribution from entrants and exits by comparing them with the cross-year (or the starting year) average of all firms, which may not be reasonable due to the changes in the composition of firms during the examined period. Based on the widely applied Olly and Pakes (1996) decomposition, Melitz and Polanec (2012) propose a dynamic method of decomposition to take into account entry and exit effects on aggregate productivity and its growth over time. This method decomposes aggregate productivity evolution process into components that capture improvement in average productivity distribution and reallocation of market share from less productive to more productive firms while overcomes the shortfalls of the previous methods.

Melitz and Polanec (2012) show that the aggregate productivity between any two consecutive periods can be written as a function of the aggregate share and productivity of continuing survivors (i.e. $\Phi_{S t}$ ), exiters (i.e. $\left.\Phi_{X t}\right)$ and entrants (i.e. $\left.\Phi_{E t}\right)$. In particular, at the start of period $t=1$ and in the next period $t=2$, the aggregate TFP can be written respectively as:

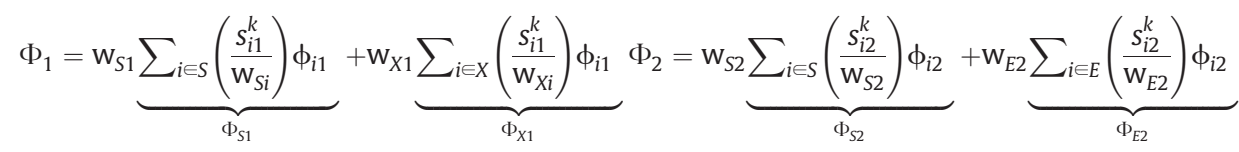

where $\mathrm{w}_{h t}=\sum_{i \in h} s_{i t}^{k} / \sum_{i} s_{i t}^{k}, h=S, X, E$ denotes the set of firms which belong to the survivors (S), the exiters (X) and the new entry (E) in the economy. This means that for any consecutive periods, the aggregate TFP in period 1 consists of the weighted average TFP of the survivors and the exits, while that of period 2 consists of the weighted average TFP of the survivors and entrants, where the survivor sets in both periods are common.

For the surviving firms, their productivity can be further decomposed into an average productivity term (or technical efficiency) and an allocation term. The average-productivity term is the unweighted mean of TFP of all the surviving firms $\overline{\phi_{S t}}=\sum \overline{\phi_{i t}} / N_{S t}$ where $\mathrm{i} \in S$ and $N_{S t}$ denotes the total number of surviving firms at time $t$. It measures the unweighted average contribution of individual surviving firm's productivity to aggregate productivity. The allocation term corresponds to the sample size-productivity covariance, which is expressed as $\operatorname{cov}\left(s_{i t}^{k}, \phi_{i t}\right)=\sum_{i \in S}\left(\frac{s_{i t}^{k}}{\mathrm{w}_{S t}}-\frac{1}{N_{S t}}\right)\left(\phi_{i t}-\overline{\phi_{S t}}\right)$. In other words, the allocation term is the mean of the multiplication terms of the differences between a surviving firm's actual share in the economy and the hypothetical average share in the economy (i.e. if resources were allocated randomly by a perfect market mechanism) and the differences between the firm's TFP and the average TFP level of all surviving firms. This means that Eq. (2) can be re-written as:

$$
\Phi_{1}=\mathrm{w}_{S 1} \overline{\phi_{S 1}}+\mathrm{w}_{S 1} \sum_{i \in S} \operatorname{cov}\left(s_{i 1}^{k}, \phi_{i 1}\right)+\mathrm{w}_{X 1} \Phi_{X 1} \Phi_{2}=\mathrm{w}_{S 2} \overline{\phi_{S 2}}+\mathrm{w}_{S 2} \sum_{i \in S} \operatorname{cov}\left(s_{i 2}^{k}, \phi_{i 2}\right)+\mathrm{w}_{E 2} \Phi_{E 2} .
$$

The formulas above describe that the aggregate TFP is attributed to average technical efficiency of the surviving firms, resource reallocation among surviving firms, and exit and entry effects.

Unlike the resource allocation measure in Foster et al. (2001) who report the inter-relationship between the market share and productivity of individual firms when compared to itself over time, the measure for resource allocation in Eq. (3) captures the joint cross-sectional distribution of market share and productivity that compares the individual TFP with the average of all surviving firms, which provides greater insight into aggregate productivity variation (Melitz \& Polanec, 2012).

Understanding these components in Eq. (3) above helps to shed light on the important contributing factors to aggregate TFP in China. However, to gain knowledge about the dynamic development of the aggregate productivity, we need to study its changes over time. Given the Eq. (3) above, Melitz and Polanec (2012) show that the changes in aggregate productivity between times $t=1$ and $t=2$ can be written as:

$$
\Delta \Phi_{t}=\underbrace{\overline{\phi_{S 2}}-\overline{\phi_{S 1}}}_{\text {Technical progress }}+\underbrace{\left[\sum_{i \in S} \operatorname{cov}\left(s_{i 2}^{k}, \phi_{i 2}\right)-\sum_{i \in S} \operatorname{cov}\left(s_{i 1}^{k}, \phi_{i 1}\right)\right]}_{\text {Resource allocation of survivor }}+\underbrace{w_{X i}\left[\Phi_{S 1}-\Phi_{X 1}\right]}_{\text {Gains from exit }}+\underbrace{w_{E 2}\left[\Phi_{E 2}-\Phi_{S 2}\right]}_{\text {Gains from entry }},
$$


where the first term, technical progress, represents the aggregate productivity growth due to the average productivity improvements of the survivors, while the second term represents the improvements due to the resource allocation among survivors; the third term represents the gains in TFP growth by firm exits and the last term represents the gains from the entrants. The last three terms together indicate the total resource allocation effects in the aggregate TFP growth.

As shown in Eq. (4), the contribution of exiting firms to aggregate productivity growth is compared to surviving firms at time $t=1$, while the contribution of entering firms to aggregate productivity growth is compared to surviving firms at time $t=2$. This sets Melitz and Polanec (2012) method apart from the earlier decomposition methods by Baily et al. (1992), Griliches and Regev (1995) and Foster et al. (2001), where the exits and entrants are compared to average productivity of all firms between the two periods. Melitz and Polanec (2012) construct the contribution for exiting and entering firms on a more rational "counterfactual" case, where the aggregate productivity gains are derived from comparing exiting and entering firms with their surviving peers in the same periods.

The exiting literature has abundant evidence on state ownership being one of the major sources of economic inefficiency (Megginson \& Netter, 2001), due to its obstruction to competition (Sheshinski \& López-Calva, 2003), incomplete contracting inability (Laffont \& Tirole, 1993; Shleifer, 1998), governments' intervention (Sappington \& Stiglitz, 1987), as well as soft budget constraints for inefficient and unviable SOEs (Jefferson \& Su, 2006). Given our main objective is to identify the role of the state ownership in contributing to the components of aggregate productivity in Chinese economy, we next examine the different patterns of technical efficiency and progress and resource allocation between the state and the non-state sector. Firms are grouped into four categories of state-owned, private, recently privatized, and recently nationalized. A firm is classified as a recently privatized (nationalized) firm if it is owned by the state (private) at $t=1$ and is owned by the private (state) at $t=2$. We then modify Eqs. (3) and (4) by decomposing the group-weighted components of average aggregate productivity and growth, to obtain the decomposed contribution of each group.

We allow the cross-ownership resource allocation by calculating the contribution of the surviving, exiting and entering firms of different ownership to aggregate TFP based on the market share and average TFP of all surviving firms, rather than the surviving firms of the same ownership group. In this way the comparison of productivity levels and market shares between firms of each ownership group is made with the economy-wide average surviving firms. This allows us to fully capture the resource re-allocation between firms. Hence the calculated resource allocation efficiency encompasses both the within-sector (the state, private, privatized and nationalized) re-distribution of resources and the re-distribution of resources across sectors.

An alternative to the above decomposition method is within ownership decomposition, which can be done by decomposing aggregate TFP for different sectors separately. This would mean that the base group is restricted to the firms of the same ownership type. Hence one could only capture resource allocation among firms of the same ownership type, while ignore the cross-ownership resource allocation. Consequently, only partial resource allocation is observed. Nevertheless, we applied this approach as an experiment, by conducting the within-sector TFP and growth decomposition for the state and private sectors separately, and count ownership changes as exits from the previous sector and new entries to the other sector. The results for resource allocation are qualitatively similar with the cross-ownership resource allocation approach that will be discussed in Section 4. Quite interestingly but not surprisingly, purely within-sector resource allocation efficiency is considerably worse in the state sector. ${ }^{5}$

Before we carry on with the analysis, it is worth pointing out the potential limitations of our TFP decomposition approach. As shown earlier, Melitz and Polanec (2012) approach possesses a number of advantages over the previous methodologies for being more accurate in constructing counterfactuals and more direct in measuring TFP improvements. Nevertheless, the approach relies on the underlying assumption that the relationship between productivity level and market share allocation is positive, which implies that the resource allocation will improve if market share is re-allocated from less productive firms to more productive ones. Hence it is useful to bear in mind that when there is no direct positive link between firm level productivity and its contribution to aggregate final demand, for the latter some may argue matters more (Basu \& Fernald, 2002; Petrin \& Levinsohn, forthcoming), the assumptions of Melitz and Polanec (2012) approach may be restrictive.

\section{Data and summary statistics}

The empirical analysis is based on the Annual Report of Industrial Enterprise Statistics compiled by the National Statistical Bureau of China (NSB) over the period of $1998-2007 .{ }^{6}$ The data covers the population of all state-owned firms and all above-scale non-state owned firms with annual sales above 5 million RMB. ${ }^{7}$ Hence it is the largest Chinese firm level dataset that is known available. The advantages of using this database is not only for its size and coverage, but also for the accumulated knowledge and experience of using the data among researchers through exploiting its potentials and mitigating its pitfalls (see for example Brandt et al., 2012; Du \& Girma, 2008; Nie, Jiang, \& Yang, 2012; Song et al., 2011).

In the construction of the final data matrix, particular attention was devoted to ensuring the consistency of the firm identification, industrial concordances and ownership classification, as well as the measurement issues of output and capital stock of production function. Following Brandt et al. (2012), we construct industrial concordances to account for industrial specification

\footnotetext{
${ }^{5}$ The results suggest that resource reallocation is not only inefficient between state and private sectors, but also poor within the state sector. This reinforces the general finding of the paper that the state sector is accountable for the resource misallocation of the economy. The results are available upon request.

${ }_{6}^{6}$ While the NBS firm level data are accessible till 2009, 1998-2007 is the most recent period of observations for which all crucial data for conducting our empirical analysis are available.

7 Approximately USD 600,000 over the examined period.
} 
changes. We also clean the data thoroughly and carefully check the consistencies and completion of the information of firm identification and ownership registration over the period.

We adopt Olly and Pakes (1996) TFP estimation procedure in the framework of a value-added based production function. Industrial value-added refers to the final results of industrial production in monetary terms during the reference period. According to the production approach defined by the Chinese statistics authority, the value added of a firm is calculated by its gross industrial output less its industrial intermediate input plus its value added tax. This in theory equals to the distribution approach method that sums wage and benefits, fixed assets depreciation and operating profit. The measure of the labor input is based on the number of employees. The investment is derived by the changes in real capital stock between the current period and the previous one, plus the forgone depreciation of the current period. Using book value of fixed capital in the production function estimation is not appropriate and causes systematic bias. Built upon the previous work by Jefferson, Rawski, and Zheng (1996), Perkins and Rawski (2008), and Brandt et al. (2012) recently develop a procedure to construct firm's original capital stock at birth year (up to 1978), and firm's incremental net fixed capital of each year, using calculated industrial historical capital stock annual growth rate by province and two-digit level industry based on the 1993 annual enterprise survey for the period of 1993-1998, and the calculated growth rates based on the NBS data since 1998. We follow their method to reconstruct real capital stock (more details see Appendix 1). Firm's output, investment, intermediate inputs and wage are deflated using different deflators, which are also explained in Appendix 1.

Firm ownership is defined according to the official registration records in the baseline decomposition analysis, and we use the results as a benchmark to allow the comparability with official statistics and other empirical results particularly based on aggregate data. In order to keep the picture simple and clear, we divide firms into state and private (or more exactly non-state firms $),{ }^{8}$ and define recently privatized and nationalized firms as discussed above. To minimize the potential influence of statistical errors in the ownership registration records, we remove around 5000 firms (about $1 \%$ of the firms in the sample) that change their ownership more than once over the period.

In this study, we only include manufacturing firms for the empirical analysis. ${ }^{9}$ We dropped firms with zero employees, firms whose fixed assets were greater than total assets, and firms with missing observations on our main variables. The possible influence of outliers was also controlled for by excluding observations in the top and bottom 1 percentile for each of the key variables in the analysis and the TFP estimate. We do not drop firms with less than 10 employees as Brandt et al. (2012) do in the analysis as this would drop out many entrants and underestimate the entry effects, which forms an important part of this study. The final data matrix presents an unbalanced panel of firms of 1.9 million observations over the examined period, ranging from 140,017 in 1998 to 350,496 in 2007. The annual attrition rate is between 9 and $15 \%$ of the whole sample of the raw data. Table 1 reports the summary statistics for the raw database in Panel I, and those of the key variables used to generate TFP, as well as the TFP estimate in Panel II. Panel I shows that the raw data closely match the Chinese official annual statistics. In comparison with the 2004 census statistics, these firms produce about $90 \%$ of all industrial outputs and employ about 70\% of all industrial workforce.

There is a considerable turnover rate in the NBS data. We define entrants by both birth year records which are reported in the data, and the actual entrance in the dataset. Therefore the entrants are accurately traced. While the exit information is also accurate for SOEs, it may not be accurate for non-SOEs, in that firms exiting from the database could also be due to their performance level falling below the scale (of sales value of 5 million RMB), although anecdotal evidence suggests that falling below the bar would not necessarily remove firms from the database. ${ }^{10}$ To mitigate the potential inconsistency, we define exits only when firms exit the database and never re-enter over the whole period. Still caution is needed to interpret the results on the exit effects for the non-state sector.

\section{Results and discussion}

This section first reports the main findings on the productivity decomposition of the whole economy (in Section 4.1) and by ownership (in Section 4.2), in the context of the productivity evolution of the Chinese firms over the last decade. We then test the sensitivities of these results to different weighting schemes and ownership definitions in the robustness checks (in Section 4.3). The final discussion section elaborates on the overall findings, links them to the literature and the broader context, and reflects on the GJMT hypothesis. To summarize the findings with more clarity, we report the results in three periods, ${ }^{11}$ including the first three years prior to the WTO entry in 2001, then between 2002 and 2004 during which many SOEs were restructured and privatized through shareholding system, and finally between 2005 and 2007 when enterprise reforms significantly slowed down (Du \& Liu, 2012).

\footnotetext{
${ }^{8}$ By our definition, the state sector includes firms with official registered state-owned enterprises (with registration code 110 ), jointly owned or operated by the state (with registration code 141), and limited companies wholly funded by the state (with registration code 151). The non-state sector then includes all other firms.

${ }^{9}$ We did not include public utilities sectors which are largely state-monopolized and hence resources are not expected to freely flow in market. Mining is also excluded because of incomplete information. There is no service sector firm-level data of a decent size.

${ }^{10}$ For non-state firms, the state policy is that above-scaled non-state firms are required to report their annual statistics to the Bureau. For firms that are belowscaled or used to be above the scale but fell off below the scale, they could skip reporting their data if they wished. Many firms carry on reporting even the sales fell below the scale in some years. The inertia of the data recording is clearly observed from the data.

${ }^{11}$ It is worth noting that the decomposition of the aggregate TFP and growth is done on the year-on-year basis, as described in Methodology.
} 
Table 1

Summary statistics.

\begin{tabular}{|c|c|c|c|c|c|c|c|c|c|c|c|c|c|}
\hline \multirow[t]{2}{*}{ Year } & \multicolumn{5}{|c|}{$\begin{array}{l}\text { I. Raw data and matching official statistics (all firms, } \\
\text { aggregate statistics) }\end{array}$} & \multicolumn{8}{|c|}{ II. Final data matrix and summary statistics (arithmetic mean) } \\
\hline & $\begin{array}{l}\text { No. of } \\
\text { firms }\end{array}$ & Employment & Output & Value-added & $\begin{array}{l}\text { Fixed } \\
\text { assets }\end{array}$ & $\begin{array}{l}\text { No. of } \\
\text { observations }\end{array}$ & Capital & Value-added & Employment & $\begin{array}{l}\text { Entrants } \\
(\%)\end{array}$ & $\begin{array}{l}\text { Exiters } \\
(\%)\end{array}$ & $\begin{array}{l}\text { Firm } \\
\text { age }\end{array}$ & TFP_OP \\
\hline 1998 & 165,118 & 62 & 6.77 & 1.94 & 5.26 & 140,017 & 25.88 & 10.89 & 332.93 & - & 17.30 & 14 & 0.94 \\
\hline 1999 & 159,048 & 58.1 & 7.27 & 2.16 & 5.59 & 132,058 & 29.2 & 12.71 & 330.54 & 16.9 & 12.20 & 14 & 0.98 \\
\hline 2000 & 162,882 & 55.6 & 8.57 & 2.54 & 5.95 & 133,210 & 29.48 & 14.29 & 312.59 & 14.4 & 18.50 & 14 & 1.03 \\
\hline 2001 & 171,241 & 54.4 & 9.54 & 2.83 & 6.34 & 143,356 & 28.18 & 15.42 & 287.83 & 26.0 & 9.30 & 13 & 1.08 \\
\hline 2002 & 181,545 & 55.2 & 11.1 & 3.3 & 6.79 & 152,674 & 26.83 & 17.66 & 274.95 & 16.8 & 12.00 & 12 & 1.13 \\
\hline 2003 & 196,206 & 57.5 & 14.2 & 4.2 & 7.55 & 163,849 & 26.63 & 20.89 & 271.43 & 18.9 & 17.70 & 11 & 1.18 \\
\hline 2004 & 275,492 & 66.2 & 20.2 & 5.71 & 9.2 & 223,637 & 21.79 & 19.06 & 225.79 & 41.0 & 4.30 & 9 & 1.19 \\
\hline 2005 & 271,812 & 68.9 & 25.2 & 7.22 & 10.6 & 239,596 & 24.04 & 22.75 & 233.47 & 12.9 & 7.10 & 9 & 1.23 \\
\hline 2006 & 301,931 & 73.6 & 31.6 & 9.1 & 12.5 & 267,290 & 24.9 & 25.6 & 225.54 & 15.9 & 7.10 & 9 & 1.27 \\
\hline 2007 & 336,732 & 78.7 & 40.5 & 11.7 & 14.7 & 305,496 & 25.52 & 28.18 & 215.62 & 17.7 & - & 9 & 1.3 \\
\hline Total & - & - & - & - & - & $1,901,183$ & 25.75 & 20.31 & 258.81 & 18.6 & 9.00 & 11 & 1.17 \\
\hline
\end{tabular}

Note: The figures reported are based on authors' own calculation using the NBS complied Annual Report of Industrial Enterprise Statistics data over 1997-2008. Panel I displays the raw data aggregate statistics where all industrial firms are included. All values are denoted in trillion RMB and employment in millions of workers. These aggregate statistics are closely line with what are reported in the China Statistical Yearbooks. Panel II reports the summary statistics of the final data matrix for our decomposition analysis, which are based on only manufacturing firms and carefully cleaned. All values are in millions RMB and employment in person.

\subsection{Findings: the whole economy}

To understand the development of aggregate productivity, we first decompose aggregate TFP in the whole economy based on Eq. (3). The results are reported in Table 2. As shown in column (1), there is a slight increase in the level of aggregate TFP in the manufacturing sector over the 10-year period. Focusing on the decomposition results, one of the striking features we discover is that the average productivity level (technical efficiency) of the surviving firms is the main component of Chinese firms' productivity (column (2)). It represents about $73 \%$ of the total TFP level in the first three years, and it rises up to $82 \%$ in the last three years. The contribution of the resource allocation among surviving firms (column (3)) is low and dropped noticeably over time, from $15.9 \%$ in the first three years to $13 \%$ towards the end period. ${ }^{12}$ The contributions of the exits (column (4)) and the entrants (column (5)) to the aggregate TFP together count for about 10\% of aggregate TFP overall, and fell considerably to just about $7 \%$ towards the end period. In sum, the contribution of resource allocation among survivors and industrial dynamics through entries and exits to aggregate TFP in the Chinese manufacturing sector appear to be not only limited, but also declining in the recent years.

Turning to TFP growth decomposition as in Eq. (4), the results reported in Table 3 reinforce the message from the TFP level decomposition. Column (2) shows that the main driver of the aggregate TFP growth has been the technical progress (i.e. changes in technical efficiency) of surviving firms, while the overall contribution of resource allocation to TFP growth is negative (column (3)). In particular, the overall negative resource allocation effect is driven by the worsening resource allocation among surviving firms (column (4)). The overall negative resource allocation effect to aggregate TFP growth is also found in Nie et al. (2012) using the same data but different decomposition methods of Baily et al. (1992) and Griliches and Regev (1995). We also find that the net effect of industrial dynamics (column (5)) is very small in magnitude, albeit overall positive. In particular, exits (column (6)) have positive effects while entries (column (7)) have largely negatively effects. ${ }^{13}$

Quite evidently, column (1) in Table 3 shows that the growth of average productivity of the Chinese manufacturing firms has slowed down over time. In the most recent three years (2005-07), TFP growth is close to zero, compared to the earlier period of $8 \%$. Our finding suggests that this considerable aggregate TFP growth decline is due to the reduction in technical progress among surviving firms. Compared with the rapid TFP growth during the earlier periods that reflects the fast cat + ching-up with the advanced economies; the significant slowdown indicates an urgent need for incumbent firms to innovate and upgrade technology in order to achieve better productivity growth.

Furthermore, the negative figures of improvement in entry (column (7)) in Table 3 show that the average TFP of new entries is on average lower than that of incumbent firms, which is also reported in Brandt et al. (2012). Brandt et al. (2012) argue that this indicates that new firms in China need to go through a period of learning before catching up with incumbents, and hence new firms per se (i.e. at least at the year of entry) are not driving up the aggregate TFP growth. Moreover, there is also a trend of falling improvement through entry over time, which indicates that the importance of entrants in driving the aggregate productivity dropped in recent years. The reduced association between firm productivity and entry effects shows declined quality of entry in

\footnotetext{
12 The contribution of the exits is $0.63 / 3.96=15.9 \%$ over $1998-2001$ and $0.52 / 3.99=13 \%$ over $2005-2007$.

13 This finding differs slightly from Nie et al. (2012) who find negative net effects of entry and exit. The difference is due to the differences in the Melitz and Polanec (2012) methodology compared to the previous ones. In the Baily et al. (1992) decomposition, the entry effect will always be positive as in the formula, regardless of the aggregate productivity of entrants, while the effect of exit to aggregate TFP will always be negative, regardless of the aggregate productivity of exiters.
} 
Table 2

Decomposition of aggregate TFP: the whole economy.

\begin{tabular}{|c|c|c|c|c|c|}
\hline & \multirow{3}{*}{$\begin{array}{l}\text { Aggregate TFP } \\
\Phi_{t}\end{array}$} & \multicolumn{4}{|l|}{ TFP decomposition } \\
\hline & & Average TFP of surviving firms & Resource allocation of surviving firms & Average TFP of the exits & Average TFP of the entrants \\
\hline & & $\mathrm{w}_{S} \overline{\phi_{S t}}$ & $\mathrm{w}_{S} \sum \operatorname{cov}\left(s_{i t}, \phi_{i t}\right)$ & $\mathrm{w}_{X t} \Phi_{X t}$ & $\mathbf{w}_{E t} \Phi_{E t}$ \\
\hline & $(1)$ & $(2)$ & (3) & $(4)$ & $(5)$ \\
\hline 1998-2001 & 3.96 & $2.89(72.98 \%)$ & $0.63(15.91 \%)$ & $0.30(7.58 \%)$ & $0.14(3.54 \%)$ \\
\hline 2002-2004 & 3.98 & $3.05(76.63 \%)$ & $0.51(12.81 \%)$ & $0.27(6.78 \%)$ & $0.14(3.52 \%)$ \\
\hline 2005-2007 & 3.99 & $3.25(81.45 \%)$ & $0.52(13 \%)$ & $0.17(4.26 \%)$ & $0.11(2.76 \%)$ \\
\hline $\begin{array}{l}\text { All year } \\
\text { average }\end{array}$ & 3.99 & $3.05(76.44 \%)$ & $0.56(14.04 \%)$ & $0.26(6.52 \%)$ & $0.13(3.29 \%)$ \\
\hline
\end{tabular}

Note: From authors' own calculation, and the components are defined as in Eq. (3). The percentage of the contribution of each component in the aggregate TFP is also calculated and reported in the parentheses. The weight is calculated based on value-added.

the later periods, and we argue that this may indicate distortions in the mechanism through which resource is allocated. Favorable entry conditions are faced by some types of firms which may not be as productive as others who face stronger and systematic entry barriers. One plausible systematic distortion might come from government's favoritism towards the state sector.

\subsection{Findings: state vs. private}

Having demonstrated the general trend of aggregate TFP growth slowdown and weak resource allocation effects in the whole economy, we now move on to investigate the role of the still significant state sector in shaping the general patterns.

\subsubsection{TFP level decomposition}

The aggregate TFP level decomposition results by ownership group are reported in Table 4. Unsurprisingly, column (1) in Table 4 shows that on average the surviving firms in the state sector are notably less productive than their counterpart in the private sector. In fact, among all four groups of firms, the state sector firms are the least productive, behind the most productive private surviving firms, privatized firms and even nationalized firms. This mirrors the verdict of the literature on the relative performance of the state and non-state sectors (for example Hsieh \& Klenow, 2009) and it is consistent with the observations from the selection patterns in the Chinese privatization (Du \& Liu, 2012; Guo \& Yao, 2005; Liu, Sun, \& Woo, 2007). In the meantime, despite the initially low productive performance, the state sector has been catching up with the private sector in recent years. By contrast, the average TFP in the private sector has stayed at more or less the same level over the same period. Towards the end, the flat movement in technical efficiency in the private sector and the fast improvement in the state sector lead to a significantly narrowing productivity gap between the two sectors.

Interestingly, column (1) of Table 4 shows that technical efficiency of the privatized firms is generally higher than surviving state firms, and also increases over time, which matches up with the level of the private surviving firms towards the end period. This is consistent with the pattern that relatively better performing state firms were kept till later periods to be privatized (Du \& Liu, 2012). Nationalized firms are less productive than both private and privatized firms throughout our sample period. Still they are more productive than state firms in the earlier period of our sample, and only become less productive in the more recent years.

Moving to resource allocation terms, we find striking contrasts between the state and private sectors. As reported in column (2) of Table 4 and illustrated in Fig. 2, resource allocation effect among surviving firms in the state sector is weak from the very

Table 3

Decomposition of aggregate TFP growth: the whole economy.

\begin{tabular}{|c|c|c|c|c|c|c|c|}
\hline & \multirow{3}{*}{$\begin{array}{l}\text { Aggregate } \\
\text { TFP growth } \\
\Delta \Phi_{t}=\text { i. }+ \text { ii. }+ \\
\text { iii. }+ \text { iv. }\end{array}$} & \multicolumn{6}{|c|}{ Aggregate TFP growth decomposition } \\
\hline & & \multirow{2}{*}{$\begin{array}{l}\text { i. Technical } \\
\text { progress of } \\
\text { surviving firms } \\
\overline{\phi_{S 2}}-\overline{\phi_{S 1}}\end{array}$} & \multirow{2}{*}{$\begin{array}{l}\text { ii. }+ \text { iii. }+ \text { iv. } \\
\text { Total resource } \\
\text { allocation effects }\end{array}$} & \multicolumn{4}{|l|}{ Among which } \\
\hline & & & & $\begin{array}{l}\text { ii. Improvement in } \\
\text { resource allocation } \\
\text { among surviving firms } \\
\sum_{i \in S} \operatorname{cov}\left(s_{i 2}^{k}, \phi_{i 2}\right)- \\
\sum_{i \in S} \operatorname{cov}\left(s_{i 1}^{k}, \phi_{i 1}\right)\end{array}$ & $\begin{array}{l}\text { iii. + iv. Improvement } \\
\text { of net entry } \\
\text { and exit }\end{array}$ & $\begin{array}{l}\text { iii. Improvement } \\
\text { in exit } \\
\mathrm{w}_{X 1}\left[\Phi_{S 1}-\Phi_{X 1}\right]\end{array}$ & $\begin{array}{l}\text { iv. Improvement } \\
\text { in entry } \\
\mathrm{w}_{E 2}\left[\Phi_{E 2}-\Phi_{S 2}\right]\end{array}$ \\
\hline & $(1)$ & $(2)$ & (3) & $(4)$ & (5) & $(6)$ & $(7)$ \\
\hline 1998-2001 & 0.080 & 0.100 & -0.020 & -0.030 & 0.010 & 0.010 & 0.003 \\
\hline $2002-2004$ & 0.010 & 0.030 & -0.020 & -0.020 & 0.000 & 0.001 & -0.001 \\
\hline $2005-2007$ & 0.004 & 0.010 & -0.010 & -0.020 & 0.010 & 0.020 & -0.005 \\
\hline $\begin{array}{l}\text { All year } \\
\text { average }\end{array}$ & 0.030 & 0.050 & -0.020 & -0.020 & 0.010 & 0.010 & -0.001 \\
\hline
\end{tabular}

Note: From authors' own calculation, and the components are defined as in Eq. (4). The weight is calculated based on value-added. 
Table 4

Decomposition of aggregate TFP: by sector.

\begin{tabular}{|c|c|c|c|c|c|c|c|c|}
\hline & $\begin{array}{l}\text { Average TFP } \\
\text { of surviving } \\
\text { firms }\end{array}$ & $\begin{array}{l}\text { Resource } \\
\text { allocation of } \\
\text { surviving firms }\end{array}$ & $\begin{array}{l}\text { Average } \\
\text { TFP of } \\
\text { the exits }\end{array}$ & $\begin{array}{l}\text { Average TFP of } \\
\text { the entrants }\end{array}$ & $\begin{array}{l}\text { Share in } \\
\text { VA (\%) }\end{array}$ & $\begin{array}{l}\text { Weighted } \\
\text { aggregate } \\
\text { TFP }\end{array}$ & $\begin{array}{l}\text { Total contribution } \\
\text { to aggregate } \\
\text { TFP }(\%)\end{array}$ & $\begin{array}{l}\text { Contribution of average } \\
\text { TFP of surviving firms } \\
\text { to aggregate TFP }\end{array}$ \\
\hline & $(1)$ & $(2)$ & (3) & $(4)$ & (5) & $(6)$ & (7) & $(8)$ \\
\hline \multicolumn{9}{|l|}{ State sector } \\
\hline 1998-2001 & 2.65 & 0.19 & 3.5 & 3.99 & 27.37 & 0.92 & 24.04 & 0.66 \\
\hline $2002-2004$ & 2.83 & -0.003 & 3.18 & 3.23 & 15.88 & 0.45 & 12.55 & 0.41 \\
\hline $2005-2007$ & 3.18 & -0.02 & 2.15 & 2.36 & 10.28 & 0.3 & 7.9 & 0.3 \\
\hline All year average & 2.86 & 0.07 & 3.09 & 3.27 & 18.79 & 0.59 & 15.75 & 0.47 \\
\hline \multicolumn{9}{|l|}{ Private sector } \\
\hline $1998-2001$ & 3.43 & 0.5 & 4.06 & 4.1 & 70.93 & 2.92 & 74.21 & 2.13 \\
\hline $2002-2004$ & 3.46 & 0.56 & 4.11 & 4 & 83.05 & 3.43 & 86.37 & 2.56 \\
\hline 2005-2007 & 3.47 & 0.57 & 4.13 & 3.92 & 89.46 & 3.72 & 91.82 & 2.93 \\
\hline All year average & 3.45 & 0.54 & 4.09 & 4.01 & 80.13 & 3.33 & 83.14 & 2.5 \\
\hline \multicolumn{9}{|l|}{ Privatized } \\
\hline 1998-2001 & 3.11 & 0.02 & & & 1.5 & 0.06 & 1.55 & 0.05 \\
\hline $2002-2004$ & 3.33 & 0.01 & & & 0.97 & 0.04 & 0.97 & 0.03 \\
\hline $2005-2007$ & 3.46 & 0.002 & & & 0.24 & 0.01 & 0.25 & 0.01 \\
\hline All year average & 3.28 & 0.01 & & & 0.96 & 0.04 & 0.99 & 0.03 \\
\hline \multicolumn{9}{|l|}{ Nationalized } \\
\hline 1998-2001 & 2.96 & 0.002 & & & 0.2 & 0.01 & 0.2 & 0.01 \\
\hline 2002-2004 & 3.19 & 0.001 & & & 0.1 & 0.001 & 0.11 & 0.001 \\
\hline 2005-2007 & 3.12 & 0.0001 & & & 0.03 & 0.001 & 0.03 & 0.001 \\
\hline All year average & 3.07 & 0.001 & & & 0.12 & 0.005 & 0.12 & 0.004 \\
\hline
\end{tabular}

Note: From authors' own calculation based on the decomposition of aggregate TFP among four groups of firms: sectors of state and private, and privatized and nationalized firms. The weights are calculated based on value-added. The first four columns report the first four unweighted components of the aggregate TFP decomposition, which are intended to give a better view of their contribution without the size effects of their sectors in the economy.

beginning and gets worse over time. It is not up to the par with its private counterparts, for which resource allocation effect is positive and slightly increasing. While in the private sector, resources flow from less productive to more productive firms, and contribute positively to the aggregate economy, the opposite seems to be the case in the state sector. This describes that productive firms do not manage to grow bigger when they are supposed to, while unproductive state firms expand in size when they should contract. What it manifests is the diversion of resources away from more productive use. In addition, the results also suggest that resource misallocation deteriorated in the last period of 2005-2007.

Turning to the results on nationalized firms, interestingly but not surprisingly, the nationalization seems to have scored against both goals with worsened resource allocation and declined productive efficiency. In contrast, we find that the average TFP among privatized firms improves over the years. Yet what is common for both groups is that the resource allocation effects fall considerably over time, suggesting that neither type of ownership restructuring on average achieved improving resource allocative efficiency. This again indicates distortions in resource allocation that more productive privatized firms do not manage to expand as they should, while less performing nationalized firms continuously survive in the scales that are theoretically unsustainable.

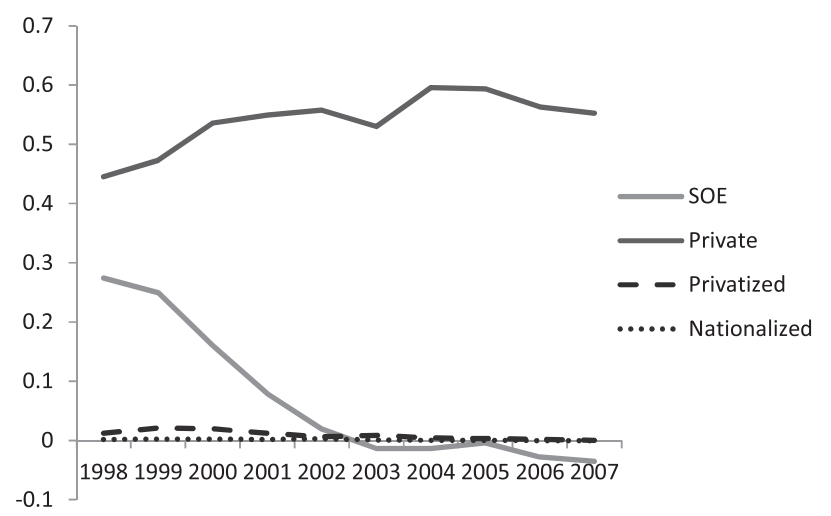

Fig. 2. Resource allocation for the surviving firms in different sectors with value added weight. From authors' own calculation. The lines in figure represent the resource allocative efficiency of surviving State, Private, Privatized and Nationalized firms in China between 1998 and 2007. 


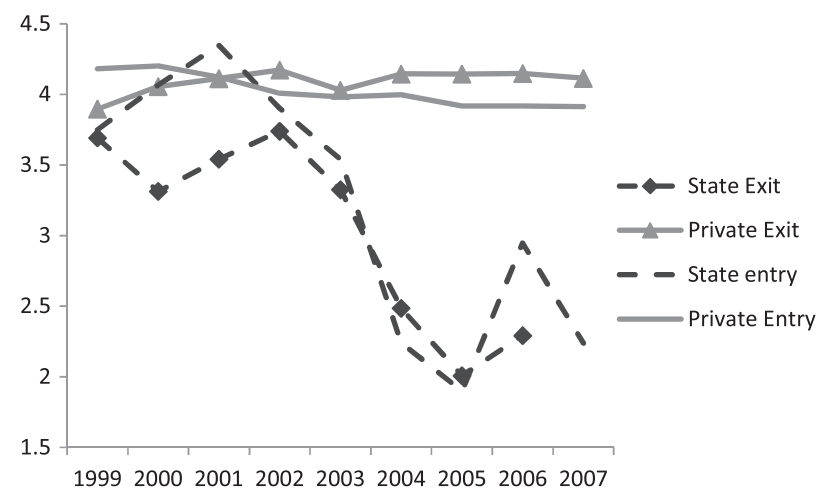

Fig. 3. Average TFP of exit and entry for state and private sectors with value added weight. From authors' own calculation. Lines above represent the average TFP of exit and entry for state and private sectors.

Similar contrasts can also be found from the average TFP of exits and entries in the state and private sectors as reported in columns (4) and (5) in Table 4. Complementing them, Fig. 3 shows that in the state sector the average TFP level of exits drops sharply over time, reflecting a combination of changing trends in the privatization reform and a worsening resource reallocation effect. It appears that SOEs are less likely to die as time goes by, and hence the TFP gap between exiting state firms and continuous surviving firms widened over time. This is consistent with the observation that, when the macroeconomic conditions improved after 2004, the pace of the privatization has slowed down considerably, and SOEs tend to remain state-owned (Du \& Liu, 2012). This also shows that as the enterprise reforms carry on, shutting down SOEs is a much less applied means to improve the state sector's aggregate performance compared to the earlier reform years (Liu, 2008).

Column (3) of Table 4 shows that the average TFP in the private exiting firms is much higher than the state exits, and is also higher than that in surviving firms, which further increases over time. Put simply, productive firms in the private sector exit the market while they would not if they were state-owned. It is worth noting that, as explained earlier, exits of the private firms might also take place when their turnover fails to reach the scale threshold. Even though the private exits did not really go bust, it is nevertheless concerning that the more productive firms do not manage to generate enough revenue to be included in the aggregate statistics. ${ }^{14}$ Fig. 3 also indicates that entrants from the private sector are more productive than their state counterparts over the entire sample period. ${ }^{15}$

Shown in Table 4, as a result of both falling (but still large) presence in the economy as measured by the share in value-added (column (5)) and worsening resource allocation (column (2)), the state sector's contribution to the aggregate TFP in China fell significantly, from $24.04 \%$ in 1998-2001 period to merely $7.9 \%$ in 2005-2007 period as reported in column (6). This implies that the importance of the state sector in China is falling in terms of not only the output (i.e. value added) but also the contribution to the aggregate TFP. Clearly the relatively large share of the state sector in Chinese economy paired with low productivity has been a continuous drag to the aggregate productivity of the economy.

\subsubsection{TFP growth decomposition}

Further to the patterns depicted through decomposing the aggregate TFP level, the TFP growth decomposition results shed lights on the dynamics of the two sectors' contribution in the aggregate productivity growth in China. In Table 5, the changes in aggregate TFP level for the four types of ownership are reported in column (1). It reveals how the average TFP growth in the four ownership groups evolves over time without counting the effects of the changes in their relative presence in the economy. The growth rate of the private sector is almost twice as high as that of the state sector, which has been found before (Brandt et al., 2012).

Concentrating on the ownership contribution to the aggregate TFP growth after taking into account the weight changes of each group of firms in the economy, Table 5 shows that the contribution of the state sector in the sample period, although improving over time, stays below zero (column (2)). The overall negative contribution is strong and driven by the diminishing presence of the state sector in the aggregate economy, the negative technical progress (column (3)), the negative resource allocation effects among surviving state firms (column (5)), and the new state entries (column (8)). It is interesting to note that the only positive contribution comes from exits in the state sector, showing the cleansing effects of letting go the unviable state firms on aggregate TFP growth. We also observe reducing magnitude of the negative contribution towards aggregate TFP growth due to the overall improved average TFP in the state sector, which is discussed in the previous section. The contribution of the state sector to aggregate technology progress is still negative as reported in column (3). Although the state sector aggregate

\footnotetext{
14 It may be useful to remind the reader that we define exits when a firm exits and never returns to the sample over the whole period.

15 However, the superior productive efficiency of private entrants may be driven by the selection effects of private firms that are included in the census according to the required production scale. In order to assess more accurately the resource misallocation effects among entrants, more appropriate datasets on startups and small-and-medium sized enterprises are needed.
} 
Table 5

Decomposition of aggregate TFP growth: by sector.

\begin{tabular}{|c|c|c|c|c|c|c|c|c|}
\hline \multirow[b]{3}{*}{ Column } & \multirow{3}{*}{$\begin{array}{l}\text { Changes in } \\
\text { aggregate } \\
\text { TFP } \\
\\
(1)\end{array}$} & \multirow{3}{*}{$\begin{array}{l}\text { Total } \\
\text { contribution } \\
\text { to aggregate } \\
\text { TFP growth } \\
\\
(2)\end{array}$} & \multirow{3}{*}{$\begin{array}{l}\text { i. Contribution } \\
\text { to technical } \\
\text { progress of } \\
\text { surviving firms } \\
\\
(3)\end{array}$} & \multirow{3}{*}{$\begin{array}{l}\text { ii. }+ \text { iii. }+ \text { iv. } \\
\text { Contribution to } \\
\text { total resource } \\
\text { allocation effects } \\
\\
(4)\end{array}$} & \multicolumn{4}{|l|}{ Among which } \\
\hline & & & & & $\begin{array}{l}\text { ii. Contribution to } \\
\text { improvement in } \\
\text { resource allocation } \\
\text { among surviving } \\
\text { firms }\end{array}$ & $\begin{array}{l}\text { iii. }+ \text { iv. } \\
\text { Contribution } \\
\text { to improvement } \\
\text { in net entry } \\
\text { and exit }\end{array}$ & $\begin{array}{l}\text { iii. Contribution } \\
\text { to improvement } \\
\text { in exit }\end{array}$ & $\begin{array}{l}\text { iv. Contribution } \\
\text { to improvement } \\
\text { in entry }\end{array}$ \\
\hline & & & & & (5) & (6) & $(7)$ & $(8)$ \\
\hline \multicolumn{9}{|l|}{ State } \\
\hline 1998-2001 & 0.093 & -0.14 & -0.09 & -0.05 & -0.07 & 0.01 & 0.01 & -0.0001 \\
\hline 2002-2004 & -0.003 & -0.11 & -0.09 & -0.02 & -0.03 & 0.01 & 0.01 & -0.001 \\
\hline 2005-2007 & -0.028 & -0.02 & -0.02 & 0.005 & -0.01 & 0.01 & 0.02 & -0.002 \\
\hline All year & 0.044 & -0.09 & -0.07 & -0.02 & -0.03 & 0.01 & 0.01 & -0.001 \\
\hline \multicolumn{9}{|l|}{ Private } \\
\hline 1998-2001 & 0.145 & 0.17 & 0.19 & 0.03 & 0.03 & -0.001 & -0.01 & 0.004 \\
\hline 2002-2004 & 0.074 & 0.13 & 0.12 & 0.01 & 0.02 & -0.01 & -0.01 & 0.0001 \\
\hline 2005-2007 & 0.087 & 0.01 & 0.03 & -0.02 & -0.01 & -0.005 & -0.004 & -0.002 \\
\hline All year & 0.088 & 0.11 & 0.11 & 0.01 & 0.01 & -0.004 & -0.01 & 0.001 \\
\hline \multicolumn{9}{|l|}{ Privatized } \\
\hline 1998-2001 & 0.138 & 0.001 & 0.002 & -0.0001 & -0.0001 & & & \\
\hline 2002-2004 & 0.018 & -0.01 & -0.01 & -0.003 & -0.003 & & & \\
\hline 2005-2007 & 0.144 & -0.004 & -0.002 & -0.001 & -0.001 & & & \\
\hline All year & 0.088 & 0.11 & 0.11 & 0.01 & 0.01 & -0.004 & -0.01 & 0.001 \\
\hline \multicolumn{9}{|l|}{ Nationalized } \\
\hline 1998-2001 & 0.094 & -0.001 & -0.001 & 0.00002 & 0.00002 & & & \\
\hline 2002-2004 & 0.022 & -0.001 & -0.0005 & -0.001 & -0.001 & & & \\
\hline 2005-2007 & -0.115 & -0.0003 & -0.0002 & -0.0001 & -0.0001 & & & \\
\hline All year & 0.088 & 0.11 & 0.11 & 0.01 & 0.01 & -0.004 & -0.01 & 0.001 \\
\hline
\end{tabular}

Note: From authors' own calculation based on the decomposition of aggregate TFP growth among four groups of firms: sectors of state and private, and privatized and nationalized firms. The weights are calculated based on value-added.

resource allocation effects are improving over the years, but over our sample period the average is still negative (column (4)). This mainly resulted from a negative resource allocation of state surviving firms (either within the state sector or between state and other sectors), and the inferior TFP of the new state entries compared to the average incumbent firms, which are exemplified by columns (5) and (8) of Table 5.

The picture for the private sector looks better, and certainly different from the state sector. The contribution of the private sector to aggregate TFP growth is generally positive, but the results reveal a clear trend of TFP growth slowdown over time. The falling contribution of the private sector to aggregate TFP growth (column (2) in Table 5) is due to the significant slowdown in technical progress (column (3)), the slump in improvements in resource allocation of the surviving firms (column 5), the more efficient private firms (compared with the average incumbents) that exit the market (column (7)) and the less efficient firms entering the market (column (8)). The contrasting pictures among entrants in the two sectors highlight the resource misallocation effects on the market entry. It is also noteworthy that the contribution of the entry effects in the private sector decreases over time, suggesting that private entrants do not act as an effective driver of aggregate TFP growth in recent years as earlier years.

For the privatized and nationalized firms, the results are largely consistent with what we observe from the level decomposition in the previous discussion. Their contributions to aggregate TFP growth are negative throughout the sample period, although the figures are very small and hardly economically significant. The negative contributions can be in part attributed to the fewer ownership changes over the period.

\subsection{Robustness check: strategy and results}

\subsubsection{Sensitivity of weighting scheme}

Using different weighting schemes in decomposition makes implicit assumptions about firms' presence in the economy, and how individual firms' productivity contributes to the aggregate productivity. It is hence an important choice to make when applying decomposition methods as the choice of weighting scheme affects the results. The value-added based weighting scheme is adopted in the above benchmark analysis. It assumes that a productive firm with higher value-added contributes more towards aggregate productivity than a same productive firm with less value-added.

To ensure that our results are not driven by the choice of weight, we test the sensitivities of using different weighting schemes. The first alternative is a popular choice in the existing productivity decomposition studies (among others, Olly \& Pakes, 1996) for good reasons. Labor is an important factor of production. Labor movement, in particular the movement of high-productive labor reflects important structural changes and allocative efficiency improvement. However, using employment weight assumes that firms with larger employee size contribute more to the aggregate productivity. This assumption can be problematic in our 
context. With part of their traditional function being to provide jobs, SOEs tend to be large in employment size, and over-employment is arguably counter-productive instead of actually contributing to the aggregate productivity.

Another alternative weighting scheme uses total fixed capital, which is often used to measure firm size in the literature. Along this line, firms with higher capital formation contribute higher to the aggregate productivity. Different from the value-added weight scheme which assumes resource allocation through production, this approach assumes that the resource allocation happens through input markets. However, SOEs enjoy soft budget constraints and generous government subsidies, which means that they would be able to accumulate capital more easily and less costly (Du \& Girma, 2008). As a result, using employment or fixed capital weights is likely to exaggerate the contribution of the state firms in the aggregate economy. Therefore, using these weights may bias our decomposition results upwards or downwards, depending on the relative productivity performance and input shares of the state sector relative to the private sector. For that reason, the value-added approach is preferred. We nevertheless test the sensitivity of using different weights. It is reassuring to report that the results we obtained are quite consistent.

Table 6 columns (2) and (3) demonstrate the consistent results. Furthermore, we also find some additional interesting results. The contribution of resource allocation among surviving firms to aggregate TFP is even more limited for the private sector when employee and fixed asset weights are used (the 9th row). This strongly confirms our earlier conjecture about the possible distortions in the input markets. Besides, using employment and fixed capital weights exacerbates the entrants' negative contribution to the aggregate TFP growth. Comparing these results with those in the benchmark analyses, it is clear that when inputs are used to measure firm presence in the economy, the private sector is underrepresented in deriving the resource allocation effect. This shows that the redistribution of inputs towards the private sector is less affluent relative to the output that it produced. In other words, there are systematic impediments in the Chinese economy that restrict the reallocation of labor and capital resources to productive private firms.

Table 6

Decompose aggregate TFP and growth for state and private sector: using different classification of ownership.

\begin{tabular}{|c|c|c|c|c|c|c|}
\hline \multirow{2}{*}{$\begin{array}{l}\frac{\text { Benchmark }}{\text { Registered }} \\
\text { ownership }\end{array}$} & \multicolumn{3}{|c|}{ Different weights } & \multicolumn{3}{|c|}{ Different ownership definition } \\
\hline & $\begin{array}{l}\text { Employment } \\
\text { weight }\end{array}$ & $\begin{array}{l}\text { Fixed asset } \\
\text { weight }\end{array}$ & $\begin{array}{l}\text { State } 50 \% \text { of } \\
\text { equity share }\end{array}$ & $\begin{array}{l}\text { State } 75 \% \\
\text { equity share }\end{array}$ & $\begin{array}{l}\text { State } 25 \% \\
\text { equity share }\end{array}$ & $\begin{array}{l}\text { Relative state } \\
\text { owned in } \\
\text { equity share }\end{array}$ \\
\hline (1) & $(2)$ & (3) & (4) & (5) & (6) & $(7)$ \\
\hline
\end{tabular}

Decompose TFP

State

Average TFP of surviving firms

Resource allocation of surviving firms

Average TFP of the exits

Average TFP of the entrants

Share in VA (\%)

Weighted aggregate TFP

Total contribution to aggregate TFP (\%)

Private

Average TFP of surviving firms

Resource allocation of surviving firms

Average TFP of the exits

Average TFP of the entrants

Share in VA (\%)

Weighted aggregate TFP

Total contribution to aggregate TFP (\%)

Decompose TFP growth

State

Total contribution to aggregate TFP growth

Contribution to technical progress of surviving firms

Contribution from total resource allocation

Contribution to improvement in resource

allocation among surviving firms

Contribution to improvement in net entry and exit

Contribution to improvement in exit

Contribution to improvement in entry

Private

Total contribution to aggregate TFP growth

Contribution to technical progress of surviving firms

Contribution to total resource allocation

Contribution to improvement in resource allocation among surviving firms

Contribution to improvement in net entry and exit

Contribution to improvement in exit

Contribution to improvement in entry

$\begin{array}{rr}2.86 & 2.88 \\ 0.07 & 0.07 \\ 3.09 & 2.99 \\ 3.27 & 3.10 \\ 18.79 & 20.43 \\ 0.59 & 0.67 \\ 15.75 & 19.41 \\ & \\ 3.45 & 3.45 \\ 0.54 & 0.06 \\ 4.09 & 3.30 \\ 4.01 & 3.22 \\ 80.13 & 78.22 \\ 3.33 & 2.75 \\ 83.14 & 79.19\end{array}$

2.86
0.17
3.26
3.33
27.91
1.02
27.73

3.45
0.21
3.44
3.37
70.51
2.64
71.68

\subsection{4}

0.08

3.04

3.72

16.71

0.57

14.31

3.45

0.54

4.11

3.98

80.88

3.33

83.39

$\begin{array}{rr}-0.090 & -0.075 \\ -0.070 & -0.065 \\ -0.020 & -0.010 \\ -0.030 & -0.019 \\ & \\ 0.010 & 0.009 \\ 0.010 & 0.010 \\ -0.001 & -0.004 \\ & \\ 0.110 & 0.135 \\ 0.110 & 0.122 \\ 0.010 & 0.013 \\ 0.010 & 0.014 \\ & \\ -0.004 & -0.002 \\ -0.010 & 0.012 \\ 0.001 & -0.012\end{array}$

$-0.428$

$-0.364$

$-0.063$

$-0.075$

0.012

0.013

0.004

$\begin{array}{ll}0.002 & -0.006 \\ 0.013 & -0.006\end{array}$

2.89
0.05
2.98
3.63
13.90
0.46
11.42

3.45
0.57
4.10
3.98
84.02
3.46
86.60

3.01

0.13

3.20

3.90

23.40

0.84

21.19

3.44

0.48

4.11

3.98

73.32

3.02

75.58

$-0.425$

$-0.362$

$-0.063$

$-0.075$

$-0.414$

$-0.354$

$-0.060$

$-0.072$

$-0.0003$

0.011

0.013

$-0.0004$

0.012

0.013

$-0.0001$

0.192

0.179

0.013

0.019

$-0.044$

$-0.054$

0.010

0.011

$-0.002$

0.150

0.150

0.010

0.016

0.000

0.006

$-0.006$

$-0.005$

$-0.006$

$-0.014-0.0004$

-0.006
-0.006

$-0.0004$

$-0.0003$

$-0.006$

Note: From authors' own calculation with different equity share as definition for ownership. 


\subsubsection{Sensitivity of ownership definition}

In the baseline analysis, we treat firm ownership as given by official registration records. Several recent studies argue that official ownership registrations may not capture firms' real ownership structure (Ayyagari et al., 2010). We address this issue by using alternative ownership definitions.

More specifically, we define firm ownership based on firm equity capital structure and investigate if this alters our main results. A firm is considered state-owned if the percentage of state appropriation in total equity capital is above a threshold; otherwise it is considered private. Three different thresholds are experimented. We first follow the earlier studies that adopt the threshold of 50\%; then we follow the Chinese tax practice according to which a firm is classified state-owned if more than $25 \%$ of received capital is by state appropriation. We then impose a high threshold of $75 \%$ state capital in the received capital. We also consider the case of relative state control, where the capital share of the state is higher than the other owner types but not necessarily higher than $50 \%{ }^{16}$

The results, as summarized in columns (4)-(7) in Table 6, are generally in line with the baseline results regardless of the threshold chosen. Moreover, a higher equity threshold leads to a lower average TFP and resource allocative efficiency in the state sector, which indicates a possible negative correlation between the share of state equity and both the technology and allocative efficiency.

\subsection{Summary and discussion}

Our findings of the aggregate productivity decompositions in the Chinese manufacturing industries, proved insensitive to the choices of weighting scheme and ownership definition, convey two clear and important messages. First, there is a general trend of productivity growth slowdown. Second, this general trend pertains to systematic resource misallocation in the manufacturing sector, where less efficient state-owned firms are more likely to enter markets, more likely to expand the size, and less likely to exit, compared to their private counterparts. This implies that resources have been driven away from productive uses, a feature that is particularly to the disadvantage of the private sector. We discuss these two messages in turn.

In the making of the great success story of China's economic miracle, the underpinning high productivity growth has contributed a great deal (Aiyar et al., 2013). The recent studies, mainly using aggregate statistics, examine the Chinese TFP evolution and try to identify the determinants of the patterns. Although it is difficult to compare the magnitudes of the previous estimates directly with ours, considering different measurements of production elements and estimation methodologies are employed, evidence derived from this study fortifies several previous studies on the slowdown of TFP growth trend in China. For example, Zheng and $\mathrm{Hu}$ (2006) find that TFP growth fell dramatically during 1995-2001 based on provincial data, while Zheng, Bigsten, and Angang (2009) further explore the reasons behind the slowdown. Jefferson, Rawski, Thomas, Wang, and Zheng (2000) investigate industrial productivity during 1980-96 finding long-term productivity growth but at declining rates during the 1990s. Taking a closer look at the overall slowdown by ownership, we argue that despite that the technical efficiency levels of the state firms are catching up with the private sector, the overall resource allocation of the state sector is still negative and acts as a significant drag of the aggregate productivity. On the other hand, while resource allocation is more desirable in the private sector, their slump performance in productivity growth has been costly for the economic growth. In particular, as the private sector holds a higher stake in the Chinese economy, the slowdown of the technical progress of its surviving firms is arguably contributive for the overall TFP slowdown in China.

As for the explanations of the slowdown at the macro level, some argue that changes in economic policies and institutional setting may temporarily affect a country's growth rate by affecting the TFP level without affecting its growth rate in the long run (Zheng et al., 2009). Others with micro-level evidence contend that many Chinese firms' productivity and efficiency performance are less than satisfactory and hardly driven by technological innovation. Heated discussions still carry on focusing on the role of capital accumulation, factor allocation (Zheng et al., 2009) and institution (Bils \& Klenow, 2001) in sustaining productivity growth. Recent cross-country comparisons and individual country case studies point to resource misallocation across firms within a given industry as an important contributing factor of the large and persistent dispersion in aggregate productivity (Bartelsman et al., 2013; Hsieh \& Klenow, 2009). McMillan and Rodrik (2011) argue that a country's economic policy in directing resources to certain sectors may lead to grow-reducing structural changes between sectors, as it happened in some Latin countries. In China, as our second message conveys, resources directed to the state sector suffer from systematic and serious misallocation, more specifically as we have shown, compared to the private firms; much less efficient state firms are allowed to enter the market, survive and expand, which amounts to growth-reducing structural change. State-owned firms are at the center of the impediments of efficient resource allocation, which crowds out the more efficient private sector despite more than two decades of reform to promote open and free markets.

How does the resource-misallocation happen and what does it mean to the private firms in China? The private sector in China has come a long way to reach their status in the economic society today. Only two and a half decades ago, private businesses were merely "allowed existing"17; today they are the pillars of the economy. The number of the individually owned businesses has increased from 98,000 in 1978 to 10.9 million in 2010, by just about 110 folds. The last decade has seen the high growth in the private sector turnover by more than $30 \%$ and their increasing contribution to the aggregate economy. Over this period, the

\footnotetext{
16 We thank an anonymous referee of the journal for this suggestion.

17 In the Thirteenth National Congress of the Chinese Communist Part (CPC) in 1998, the Central committee explicated the 16-character guideline to treat private businesses: to allow existing, strength management, promote what is beneficial and abolish what is harmful, and guide step by step.
} 
private sector contributes to one-third of GDP and created four-fifth of all the new employment. However, the most important driver of the economy needs to fight hard for their presence and fair treatment in the economy.

Broadly speaking, entry barriers and unfair competition are the main avenues in which private businesses may be discriminated against. Although we have major gaps in our knowledge about the exact ways entry barriers may exert influence, lots of anecdotal evidence records cases of entry barriers to the private firms. For example, private ownership is still grossly under-represented in many lucrative sectors. Till 2010, private investment accounted for less than $15 \%$ of the electricity and heat generation sector, and less than $10 \%$ of the financial services and telecommunications. Interestingly, it fares worse than its foreign counterparts: where foreign investors are allowed to invest in 62 out of 80 plus sectors, private investors have access to just 42 sectors. ${ }^{18}$ Even in the competitive sectors where private businesses are in principle allowed to enter, the entry cost may be much higher, if it is at all possible. There are numerous forms of entry barriers, including extremely lengthy and cumbersome entry administrative procedures and high administrative costs (Gregory, Tenev, \& Wagle, 2000).

Moreover, private enterprises are often found unable to operate in the same business conditions and receive the same government treatments as state-owned firms and foreign-invested firms (Zheng \& Yang, 2009), in some important aspects of accessing key factors of production including land (Chen, 2011), and formal finance (Allen et al., 2005). Moreover, domestic private businesses are levied with the heaviest tax compared to foreign-invested firms and the state firms (Chen, 2011). Often local governments issue various fees and charges to private sector firms particularly when they are in fiscal deficits (Chen, 2011). As a response, private enterprises are seen putting on a "red hat" ${ }^{19}$ through political affiliations (Du \& Girma, 2008; Hsueh, 2011; Zhou, 2009), developing and exploiting their relational social capital with government officials, bank officials, and executives of other firms (Cai, Fang, \& Xu, 2011; Du, Guariglia, \& Newman, 2013), aiming to improve their unfavorable status in the hierarchy. These findings reflect the existence of entry barriers in the unleveled playground and the lack of resource allocation mechanisms through market in China.

Reflecting on the puzzle of the GJMT debate, the evidence suggests that both sides of the debate have grounds. From the viewpoint of the state's presence in the economy, we can conclude that the state has not advanced; instead, it shrank. On the other hand, we find consistent and strong evidence of the systematic resource misallocation attributed to the state sector over the examined period. The continuing survival and the expansion of the inefficient state firms impelled by nonmarket forces indicate the advances of the state sector at the expense of the deprivation of the private sectors. Hence it provides clear support for the view that the state sector advanced and the private sector retreated in the recent years in China, which consequently contributed to the slowdown of aggregate productivity. It is beyond the scope of this paper to systematically examine the specific channels through which resource misallocation takes place; it is nevertheless a theme for important research in the future.

Given what we have discussed so far, the policy implication is clear. The aggregate productivity and its growth in China critically hinge on the improvement of productivity growth of the existing firms (both the state and private), on the enhancement of resource allocation among surviving firms, and through market creative destruction. This would imply that only encouraging firms to innovate and improve management skills is not enough; more fundamental structure changes and system reforms are called for, to improve the efficiency of allocating limited resources, removing entry barriers, and restraining state monopoly, so as to allow the benefits of the competitive forces to keep on coming through.

\section{Conclusion}

Recently, the repeated reports on the controversial phenomenon of "the state sector advances and the private sector retreats" (GJMT) has put the direction of future market reform in China into question. To understand the importance and the implications of this phenomenon, rather than only concentrating on the absolute size of the state sector in the economy, it would be crucial to consider its contribution to the recent economic growth, and to the aggregate productivity growth in particular. In this paper we examine the contribution of the state sector in aggregate productivity level and its improvement in the Chinese manufacturing industries over 1998-2007. Our empirical analysis highlights a general trend of aggregate productivity growth slowdown over the decade that is in part due to decelerated technical progress and in part due to systematic resource misallocation. Resource misallocation that is particularly attributed to the state sector and to the disadvantage of the private sector indicates the advances of the state sector at the expense of the deprivation of the private sectors. Hence it provides clear support for the view of GJMT. Furthermore, the decelerated technical progress indicates that beyond the initial catch-up, firms need technology upgrading and innovation to keep up with productivity growth. To do that, firms need to be incentivized, competition need to be established, and barriers need to be removed, so that resources could be allocated where they are supposed to be.

Having identified the existence of GJMT and the close link between the state sector and resource misallocation, a promising avenue for future research would be to investigate the precise channel(s) of such resource misallocation, and disentangle how the nonmarket forces hinder efficient resource allocation in the current market mechanism and financial system. Efforts should also be made to improve our understanding about the impetus and barriers of firms, both in the state and in the private sector, to improve technical progress.

\footnotetext{
18 http://www.eastasiaforum.org/2010/06/13/private-sector-investment-in-china-unshackling-the-engine-of-growth/.

19 "Red hat" enterprises refer to the companies that disguise their de facto private ownership using means of registering as state-owned enterprises, or obtaining a membership in the Communist party.
} 


\section{Acknowledgments}

Jun Du gratefully acknowledges the financial support of the project, "Privatisation, foreign investment and firm performance in China", funded by the Economic and Social Research Council (ESRC) (award RES-000-22-0729). The authors would like to thank Urmas Varblane, Xiaobo Zhang and Lu Ming for their constructive comments and suggestions, and the participants of the European Association of Comparative Economics Studies Workshop on Firm-Level Studies on Productivity, Trade and Innovation in Tartu and the SCERI-CCER Workshop on Inequality, Growth and the Middle-Income Trap in China in Beijing 2013. Gratitude also goes to the two anonymous reviewers of the journal. We also thank Michail Karoglou for his comments and careful proofreading. All remaining errors are our own.

\section{Appendix 1. Variable construction and deflation}

\subsection{Capital stock reconstruction}

As in many large firm-level data that are based on firms' financial statements, the NBS database does not report fixed investment. Instead, it contains a firm's capital stock at original purchase value, depreciation in the current year, accumulated depreciation, and a firm's book value of fixed capital in the current year that is calculated using capital stock at original purchase value less accumulated depreciation. The book value is hence the sum of the nominal values of a firm's capital stock of different years, and the discrepancy between the book value and real capital stock will depend on the deflation process of capital stock and firm age.

As can be easily argued, using book value of fixed capital in estimating production function is not appropriate. However, many already published papers are still seen using book value of fixed capital in estimation production function, possibly because the information needed to reconstruct real capital stock is unavailable or difficult to assemble. It is though unclear how much the systematic bias may be caused in the production function estimates by doing so.

Several researchers made important attempts in reconstructing Chinese firms' real capital stock, for example Jefferson et al. (1996), Perkins and Rawski (2008), and Brandt et al. (2012) among others. Brandt et al. (2012) recently develop a procedure to construct firms' original capital stock at birth year (up to 1978), and firms' incremental net fixed capital of each year, using calculated industrial historical capital stock annual growth rate by province and two-digit level industry based on the 1993 annual enterprise survey for the period of 1993-1998, and the calculated growth rates based on the NBS data since 1998.

We set out this project to manually collect the historical records of two-digit industrial fixed capital investment at the regional level, with the aim of deriving a more accurate estimate of industrial fixed capital growth over years and based on a more comprehensive coverage. This however could not be achieved, because of the highly inconsistent industrial classifications across provinces and years, and considerable missing records in the official statistics at the provincial level. We finally decided to follow.Brandt et al. (2012) procedure that is so far the most appropriate approach. ${ }^{20}$

\subsection{Deflation}

Firms' real capital as constructed by Brandt et al. (2012) procedure is further deflated using Brandt-Rawski deflator, which is a chain-linked price deflator based on separate price indices for equipment-machinery and building-structures. The Brandt-Rawski deflator is available till 2006, hence we extrapolate 2007 deflator based on previous years' deflators and the changing rate in ex-factory price index. Firms' total output is deflated using two-digit level industrial ex-factory price indices. Intermediate inputs are deflated using input deflator used by Brandt et al. (2012). Wage and benefit are deflated by provincial level Consumer Price Indices (CPI) over the years. The industrial level ex-factory price indices and CPI can be found in Chinese Statistical Yearbooks.

\section{References}

Aiyar, S., Duval, R., Puy, D., Wu, Y., \& Zhang, L. (2013). Growth slowdowns and the middle-income trap. IMF working paper, WP/13/71.

Allen, Franklin, Qian, Jun, \& Qian, Meijun (2005). Law, finance, and economic growth in China. Journal of Financial Economics, 77(1), 57-116.

Ayyagari, M., Demirguc-Kunt, A., \& Maksimovic, V. (2010). Formal versus informal finance: evidence from China. Review of Financial Studies, 23 (8), 3048-3097.

Bai, C. E., Lu, J., \& Tao, Z. (2006). Property rights protection and access to bank loans: Evidence from private enterprises in China. Economics of Transition, 14(4), 611-628.

Baily, M., Hulten, C., \& Campbell, D. (1992). Productivity dynamics in manufacturing plants. Brookings papers on economic activity: microeconomics. Vol. 4. (pp. 187-267). Brookings Institute.

Bartelsman, E., Haltiwanger, J., \& Scarpetta, S. (2013, February). Cross-country differences in productivity: The role of allocative efficiency. American Economic Review, 103(1), 305-334.

Basu, S., \& Fernald, J. (2002). Aggregate productivity and aggregate technology. European Economic Review, 46, $963-991$.

Bils, M., \& Klenow, P. (2001). Quantifying quality growth. American Economic Review, 91, 1006-1030.

Brandt, L., Van Biesebroeck, J., \& Zhang, Y. (2012). Creative accounting or creative destruction? Firm level productivity growth in Chinese manufacturing. Journal of Development Economics, 97, 339-351.

Cai, H., Fang, H., \& Xu, L. C. (2011). Eat, drink, firms, government: An investigation of corruption from the entertainment and travel costs of Chinese firms. Journal of Law and Economics, 54(1), 55-78.

\footnotetext{
${ }^{20}$ More details of Brandt et al (2012) procedure can be found in its online supplementary material. The Stata do file used to construct capital stock in this paper is available upon request.
} 
Chen, Zongshi (2011). Empowering state capitalism in China: The revival, legitimization and development of private enterprises. UC Berkeley Electronic Theses and Dissertations series.

Du, J., \& Girma, Sourafel (2008). Red capitalists: Political connections and firm performance. Kyklos, 63(No. 4), $530-545$.

Du, Jun, Guariglia, Alessandra, \& Newman, Alexander (2013). Does social capital affect the financing decisions of Chinese small and medium-sized enterprises? Entrepreneurship: Theory and Practice, http://dx.doi.org/10.1111/etap.12051.

Du, Jun and Liu, Xiaoxuan (2012) Selection, staging and sequencing in the recent Chinese privatization, unpublished manuscript.

Elliott, R., \& Zhou, Y. (2013). State-owned enterprises, exporting and productivity in China: a stochastic dominance approach, 36. (pp. 1000-1028). World Economy, $1000-1028$.

Foster, L., Haltiwanger, J. C., \& Krizan, C. J. (2001). Aggregate productivity growth: Lessons from MICROECONOMIC EVIDENCE. New developments in productivity analysis. : University of Chicago Press.

Gregory, Neil F., Tenev, Stoyan, \& Wagle, Dileep M. (2000). China's emerging private enterprises: Prospects for the new century. World Bank.

Griliches, Z., \& Regev, H. (1995). Firm productivity in Israeli industry: 1979-1988. Journal of Econometrics, 65, $175-203$.

Guo, Kai, \& Yao, Yang (2005). Causes of privatization in China. Economics of Transition, 13(2), 211-238.

Hall, R., \& Jones, C. (1999). Why do some countries produce so much more output per worker than others? Quarterly Journal of Economics, $114,83-116$.

Hsieh, C., \& Klenow, P. (2009). Misallocation and manufacturing TFP in China and India. Quarterly Journal of Economics, $124,1403-1448$.

Hsueh, R. (2011). China's regulatory state. Ithaca: Cornell University Press.

Hu, Angang (2012). The proof of the phenomena of Guo Jin Min Tui. 1. National Administration College (in Chinese).

Huang, Yasheng (2008). Capitalism with Chinese characteristics: Entrepreneurship and the state. Cambridge: Cambridge University Press.

Jefferson, G., Rawski, T., Thomas, G., Wang, L., \& Zheng, Y. (2000). Ownership, productivity change, and financial performance in Chinese industry. Journal of Comparative Economics, 34(1), 146-166.

Jefferson, G., Rawski, T., \& Zheng, Y. (1996). Chinese industrial productivity: Trends, measurement issues, and recent developments. Journal of Comparative Economics, 23(2), 146-180.

Jefferson, G., \& Su, J. (2006). Privatization and restructuring in China: Evidence from shareholding ownership, 1995-2001. Journal of Comparative Economics, 34(1), $146-166$.

Laffont, Jean-Jacques, \& Tirole, Jean (1993). A theory of incentives in procurement and regulation. Cambridge, MA: MIT Press.

Liu, Xiaoxuan (2008). The micro-foundation of China's market economy: 30 years reforms of Chinese enterprises, Dec. 2008. China: Shanghai Renmin Press \& Gezhi Press ((Chinese version); Oct. 2009 Cengage Learning Asia Pte Ltd, (English version)).

Liu, Guy S., Sun, Pei, \& Woo, Wing Thye (2007). What motivates and constrains politicians to privatize? The case of China. Economics Letters, 97(1), 81-86.

McMillan, Margaret S., \& Rodrik, Dani (2011). Globalization, structural change and productivity growth. No. w17143. : National Bureau of Economic Research.

Megginson, W. L., \& Netter, J. M. (2001). From state to market: a survey of empirical studies on privatization. Journal of Economic Literature, $39,2$.

Melitz, M. J., \& Polanec, S. (2012). Dynamic Olley-Pakes productivity decomposition with entry and exit. NBER working paper series 18182 . National Bureau of Economic Research.

Nie, Huihua, Jiang, Ting, \& Yang, Rudai (2012). A review and reflection on the use of abuse of Chinese industrial enterprise database. World Economy, 5 (in Chinese).

Olly, G. S., \& Pakes, A. (1996). The dynamics of productivity in the telecommunications equipment industry. Econometrica, 64, $1263-1297$.

Perkins, D. H., \& Rawski, T. G. (2008). Forecasting China's economic growth. In L. Brandt, \& T. G. Rawski (Eds.), China's great economic transformation. NY: Cambridge University Press.

Petrin, A., \& Levinsohn, J. (2012). Measuring aggregate productivity growth using plant-level data. RAND Journal of Economics, $43,705-725$.

Sappington, David E. M., \& Stiglitz, Joseph E. (1987). Privatization, information and incentives. Journal of Policy Analysis and Management, 6, 567-582.

Sheshinski, E., \& Lopez-Calva, L. F. (2003). Privatization and its benefits: theory and evidence. CESifo Economic Studies, 49(3), 429-459.

Shleifer, Andrei (1998). State versus private ownership. Journal of Economic Perspective, 12, 133-150.

Song, Z., Storesletten, K., \& Zilibotti, F. (2011). Growing like China, American Economic Review, 101 (1). (pp. 196-233), 196-233.

Syverson, C. (2011). What determines productivity? Journal of Economic Literature, 49 (326-265).

The Economist (2011). The long arm of the state, special report: China, Jun 23, 2011. The Economist.

Van Biesebroeck, Johannes (2007). Robustness of productivity estimates. The Journal of Industrial Economics, 55(3), 529-569.

Woo, Wing Thye, Lu, Ming, \& Sachs, Jeffrey D. (2012). A new economic growth engine for China: Escaping the middle-income trap by not doing more of the same. World Scientific Publishing Company.

Wooldridge, Adrian (2012, January 21). The visible hand, special report: state capitalism. The Economists.

Xu, Chenggang (2011). The fundamental institutions of China's reforms and development. Journal of Economic Literature, 49(4), $1076-1151$.

$\mathrm{Xu}$, Xiao Niao (2009). Guo Jin Min Tui (Private retreat market) is against reform and opening, economic observer. online at. http://www.eeo.com.cn/zt/50forum/ ruiping/2009/09/28/152562.shtml (in Chinese)

Zheng, Jinghai, Bigsten, Arne, \& Angang, Hu. (2009). Can China's growth be sustained? A productivity perspective. World Development, 37 (4), 874-888.

Zheng, Jinghai, \& Hu, Angang (2006). An empirical analysis of provincial productivity in China (1979-2001). Journal of Chinese Economic and Business Studies, 4(3), 221-239.

Zheng, Hongliang, \& Yang, Yang (2009). Chinese private sector development in the past 30 years: Retrospect and prospect. Discussion paper. Vol. 45.

Zhou, W. (2009). Bank financing in China's private sector: the payoffs of political capital. World Development, 37(4), 787-799. 